\title{
IT outsourcing as a factor for innovation development in small and medium-sized enterprises
}

\author{
Maria Kocot, Damian Kocot
}

\begin{abstract}
A B S T R A C T
Objective: The aim of the article is to present the innovative face of IT outsourcing based on a survey. The article shows how it influences the creation of various types of innovation. The article tries to determine whether IT outsourcing affects the stimulation of innovation in the area of small and medium-sized enterprises in the Silesian Voivodeship.
\end{abstract}

Research Design \& Methods: Primary information was collected using the survey technique and the questionnaire interview. The main research technique was the postal questionnaire. The obtained empirical data were analysed using selected statistical methods ( $\chi 2$ independence test).

Findings: Firms should be made aware of the advantages of outsourcing partnership in the field of IT in terms of creating innovation. A good practice in this respect would be to create a zone of redistribution of experience in implementing IT innovations.

Contribution \& Value Added: The subject of the impact of IT outsourcing on the creation of innovation has not been widely discussed in the subject literature so far. This article attempts to fill that gap.

\begin{tabular}{ll}
\hline Article type: & research article \\
& IT outsourcing; innovation; cooperation; outsourcing partners, \\
Keywords: & small and medium-sized enterprises (SMEs); business
\end{tabular}

JEL codes: $\quad$ F23, L20

Article received: 30 May 2020

Article accepted: 24 September 2020

\section{Suggested citation:}

Kocot, M., \& Kocot, D. (2020). IT outsourcing as a factor for innovation development in small and medium-sized enterprises. International Entrepreneurship Review (previously published as International Entrepreneurship / Przedsiębiorczość Międzynarodowa), 6(3), 91-101. https://doi.org/10.15678/IER.2020.0603.07

\section{INTRODUCTION}

The business innovation remains dependent on many issues, both exogenous and endogenous factors. Outsourcing of information technology (IT) plays a huge role among them, taking on a major role in improving the company's innovation. Innovation creation, achieved through outsourcing partnerships in the field of IT services, is a very important place. This 
cooperation becomes a response to emerging challenges in the turbulent market environment of the company. In order to create innovation, access to unique resources and the potential needed to create new innovations is essential.

Setting up an outsourcing partnership can be beneficial at any stage of the innovation process, including innovation creation, implementation and commercialisation and diffusion.

The purpose of the article is to present an innovative face of IT outsourcing based on a survey. The following research questions were proposed:

RQ1: What is the most often outsourced area?

RQ2: What are the benefits of working with an IT outsourcing partner?

Are there statistically confirmed relationships between the benefits achieved in connection with the implementation of innovations as a result

RQ3: of outsourcing cooperation and activities that are to ensure proper cooperation with an external company?

The article uses the empirical investigation conducted among small and mediumsized enterprises (SMEs) from the Silesian Voivodeship, highlighting the degree of cooperation between these firms and external actors, in the implementation of innovative activities in the field of IT.

\section{LITERATURE REVIEW}

The term "outsourcing" was based on the words "outside" (external), "resource" (measure), "using", which means shifting orders of production, services or generally business processes in whole or part of it to another firm (Szymaniak, 2008).

Definitions of external IT services emerged in the US in the 1980s Lacity and Hirschheim (1993) attempted to define outsourcing. To this end, they began to analyze the outsourcing decisions of American businesses. They described outsourcing as "the use of external companies to carry out one or more organizational activities" (Lacity \& Hirschheim, 1993). Outsourcing in the field of IT services (IT outsourcing, outsourcing of information systems, information technology, information technology), is defined as the provision of comprehensive e-business solutions by external specialists (Hindle, 1998).

IT outsourcing can also be understood as a third-party acquisition of specific activities related to IT (all or only selected areas). Its investments and ongoing IT infrastructure expenses often account for a significant part of the company's budget. IT used for a long time affects the level and quality of execution of economic processes. The company must choose its information technologies on purpose, according to clearly defined priorities and on the basis of accurate cost-effectiveness analyses. A well-developed IT strategy ensures the proper functioning of the outsourcing model. Outsourcing is part of the company's strategic plan, has a long-term nature, and the service provider becomes a partner rather than a supplier.

IT outsourcing is also defined as a process undertaken by an organization aimed at signing an outsourcing agreement and modernizing IT assets using cooperation with other customers (Kern et al., 2002). In the framework of it services and services, this is work related to the day-to-day administration of hardware and software IT resources in order to increase the effectiveness and efficiency of the business (Kłos, 2009). 
IT outsourcing consists in the fact that the organization instructs the suppliers to perform only some (partial outsourcing) or almost all functions (total/full outsourcing), but leaving its own employees the function of monitoring and controlling the whole project. Outsourcing of IT services is most often a contract outsourcing, for which the company abandons its functions in the field of IT systems and transmits their performance to an independent economic operator on the basis of a contract. IT outsourcing consists in transferring responsibility for the maintenance of the it system of the company (or part of it) to an external company in exchange for periodic (fixed) fees (Sobińska, 2008).

Any company that wants to survive in an unpredictable market environment should strive to innovate and strive to be innovative. These two terms are often identified (Chao \& Pucik, 2005). In the scientific literature, innovation is treated as an important attribute of the company. Its rationale is its ability to innovate. In turn, innovation can be determined by the ability to create something new or make significant changes (Hilami et al., 2010). The term also refers to the launch of new goods and the opening of new markets, using combinations of strategic orientation along with innovative ups and processes (Danneels \& Kleinschmidt, 2016). Innovation, on the other hand, refers to the changes made in terms of technology, organisation, economics, ecology, as well as changes in the social sphere of the organisation. These changes should be taken into practice (Klincewicz, 2014).

When defining the term "innovation", the treatment of this phenomenon as the ability of the organization to innovate (Nowacki, 2010) was emphasized. There are three levels of innovation in the organisation (Pichlak, 2012):

- the tendency to adapt innovation,

- the ability to generate innovation,

- the ability to take risks, inextricably linked to the implementation of innovation.

Innovation can be analysed both in a unit context (then determined by the unit's innovation competence) and can be considered at the organisational level (interpreted by the organisation's innovation potential) as well as at the macroeconomic level (determined at national or regional level by the ability of economic operators to seek adaptation, implementation and dissemination of innovation). The innovation of the company should be analysed through an organisational prism in which the entity's innovation potential is defined as the company's ability to implement and disseminate innovation. To a great extent, this process is conditioned by cooperation with an outsourcing partner.

When discussing the problem of business innovation, the sources of innovation need to be carefully analysed. In the past, innovation was created mainly through internal resources that were held by the company. This operating model is used to be referred to as closed innovation. However, the impact of the market environment, the ever-increasing competition and the growing needs of consumers have modified the concept of innovation in the company. In the early 21st century, the concept of "open-market innovation" emerged. The term was formulated by Rugby and Zouka from Bain \& Company and meant the use of "ideas that companies can identify in their surroundings" (Sobińska, 2008).

Outsourcing is a multidimensional phenomenon. It adopts different overtones. An extremely important place in the analysis of this phenomenon is occupied by innovative. The innovative face of IT outsourcing affects almost every stage of the external cooperation process. It is certainly important to pay attention to the possibility of creating product 
innovations that arise through the cooperation between the two sides of cooperation. Innovations are then created as a result of such cooperation (Figure 1). External experts contribute to innovation through their knowledge.

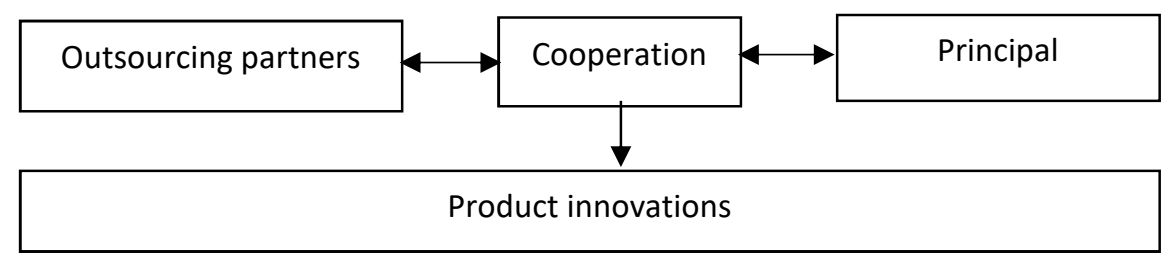

Figure 1. Product innovations as an effect of outsourcing cooperation Source: own elaboration.

However, the outsourcing relationship is not limited to the above-mentioned innovations alone. It can also lead to marketing innovations that are associated with the creation of non-product marketing values. The innovative overtone of IT outsourcing can be applied to the results resulting from it. However, not every outsourcing union has to be crowned by innovation. However, it must be said that it is really a matter of interpretation to recognise the result of outsourcing cooperation as an innovation. An identical phenomenon can be interpreted differently by researchers.

Establishing an outsourcing relationship allows to make the most of the advantages of the free market. This, in turn, causes an influx of new ideas (Luecke \& Katz 2005). Through open market innovation, it becomes possible to use unique external sources of knowledge, including from outsourcing partners, as a result to consolidate a strategic market advantage (Sankowska, 2009).

Therefore, the company's innovation should be built both through the use of the company's internal resources and through the use of external resources from $m$.in. outsourcing ratio. Given the intricacies of the innovation process, it is extremely valuable to use the knowledge of an external partner. To this end, companies should establish and maintain appropriate relationships with actors in the environment.

The process of building innovation in the company should be taken into hand in a comprehensive manner, i.e. in the context of the it should include both the use of internal resources in the company structures and the advantages of an 'open market', i.e. unique external sources, including those from the outsourcing partnership (Figure 2).

The invocation of research (Hakanson \& Snehota, 2006) makes it possible to conclude that in the modern market environment and turbulent economic reality, the establishment of an outsourcing relationship takes on an important role. This cooperation brings numerous benefits to stakeholders that will contribute to stimulating their innovation (Zakrzewska-Bielawska, 2016).

Various research carried out so far has highlighted the huge impact of external relations (including IT outsourcing partnerships) on boosting business innovation. It was found that the education of the institutional network results in the development of product innovations, and participation in the market network translates into the creation of organisational innovations.

Therefore, It can be concluded that the establishment of an outsourcing partnership has an impact on the creation of both product and organisational innovations (Kim \& Lui, 
2015), and stating holistically the development of the innovation process. In turn, the effective implementation of these innovations is conditioned by the interoperability of the network as a whole (Dewick \& Miozzo, 2004).

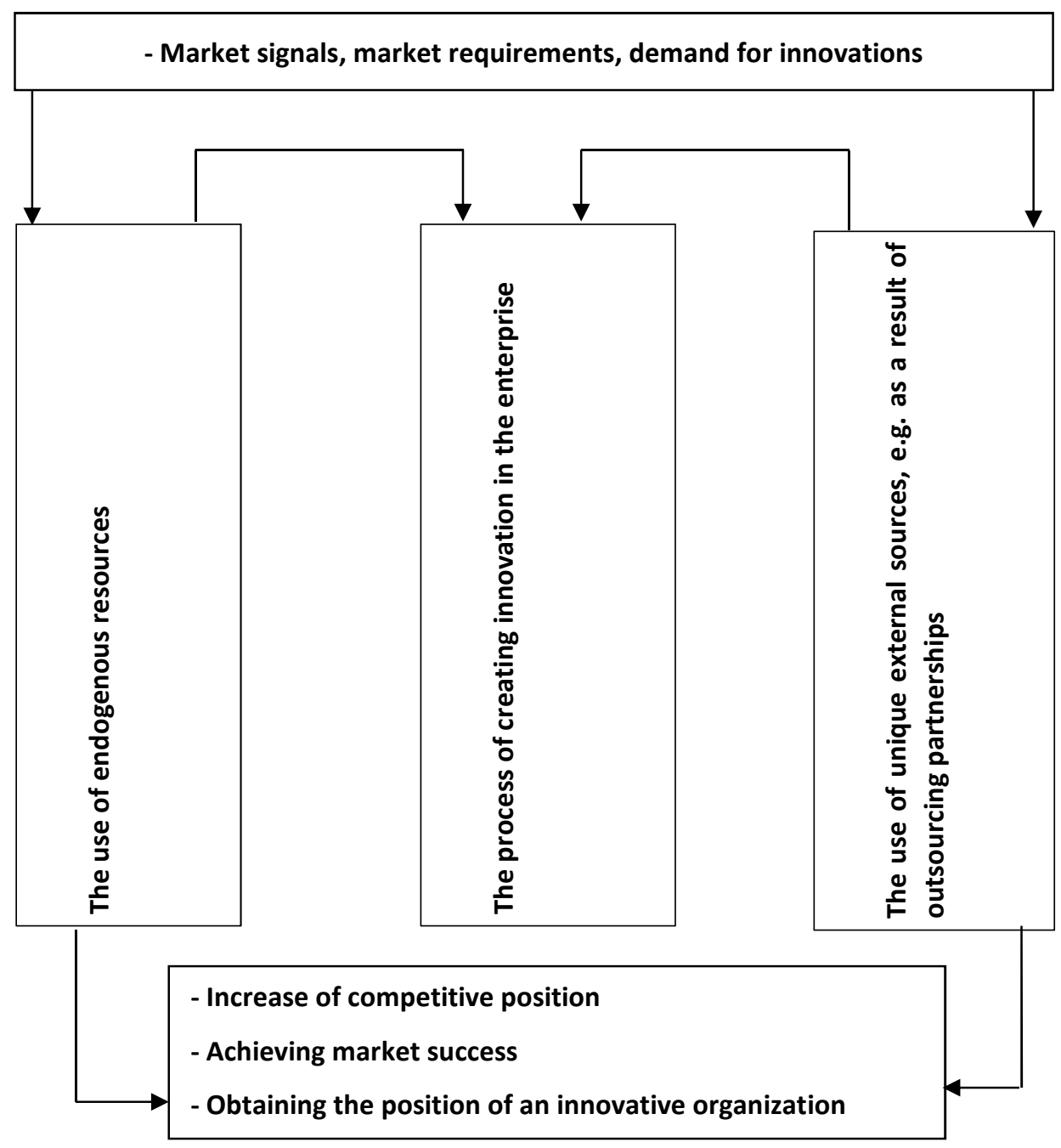

Figure 1. An integrated approach to the process of creating innovation in an enterprise Source: own elaboration.

The study also clearly indicates that outsourcing partnership facilitates the organisation with which relations have been established, the process of commercialising innovation and diffusion (Aarikka-Stenroos et al., 2014). However, different types of innovation require specific outsourcing relationships (Partanen et.al., 2014). 
The establishment of an outsourcing relationship affects the development of the capacity necessary for the company to create knowledge. Creating IT innovation requires the involvement of IT professionals. Therefore, it is not uncommon for IT professionals to use the knowledge of IT professionals (Kodama, 2007) in the process of creating innovation.

Outsourcing partnership therefore remains beneficial for the development of innovation. Especially since companies wishing to be innovative should use both internal and external ideas and the paths for their commercialisation. It is a good practice to establish cooperation with an external partner, as their innovative capabilities depend to a large extent on it. This issue remains very important in the IT industry (Sobińska \& Jakubowska, 2013).

The impact of IT outsourcing on innovation is driven by increased access to complementary resources and specific network resources. Partners also profit through solidarity, joint, R\&D costs and knowledge transfer (Klimas, 2014). The establishment of outsourcing cooperation contributes to the deepening of knowledge and also improves the absorption capacity of the company. The result is a higher level of innovation activity.

The IT area remains extremely important in the implementation of the management model in companies, based on the model of providing customers with the best experience in contact with the brand.

The it teams in the organization see that their priority is to create innovations in the digital age, necessary to stand out in the market and establish their position. Unfortunately, it is not uncommon in the field of IT to have competence gaps in the form of a shortage of professionals and skills of employees. The solution is to establish an outsourcing partnership in this area.

To improve results, low-code software development and rapid deployment (m.in cloud solutions) are in demand. A huge proportion of IT leaders want to provide business users with tools to build the applications (they want themselves, usually, due to the required level of security, to a limited extent.

IT professionals dealing with a single infrastructure often do not have the specific tools they need to solve a problem. IT outsourcing companies can fill this gap. They employ specialists from many fields. The scope of their services remains extremely wide, for example, they are engaged in the operation of all server systems, workstations, heterogeneous networks, IT security, backups or AV systems, based on various solutions and

THE GDPR. In each of these areas you can count on the expertise of an expert in a given field. Thanks to this, it becomes possible to provide services at the highest level and to propose innovative solutions.

\section{MATERIAL AND METHODS}

In the years 2018-2019, we conducted empirical research on the level of use of out-sourcing cooperation in the field of IT in the context of innovation creation. The survey was carried out among SMEs. The investigated businesses were active in the Silesian Voivodeship. The surveys took the form of the postal survey questionnaires and were con-ducted among 100 small businesses from the Silesian Voivodeship ( $n=100$ SMEs). A random sample selection was used.

The aim of the empirical study was to examine whether Silesian small and mediumsized enterprises are willing to cooperate with an IT outsourcing partner in the field of conducting innovative activities. The survey questionnaire was addressed to companies of 
different legal characteristics, which are usually privately owned. The survey was completed by one hundred representatives of small and medium-sized enterprises. It is therefore impossible to consider a research sample of such a size to be representative and, consequently, to generalize the results of the following studies for the entire SME sector of the Silesian Voivodeship. Nevertheless, the research carried out for the purposes of this article can be considered as an attempt to assess the impact of IT outsourcing on the level of innovation of small and medium-sized enterprises in the Silesian Voivodeship.

More than half of the surveyed respondents were micro-enterprises (54\% of the total sample), while $28 \%$ of respondents were small businesses, and $18 \%$ of respondents were medium-sized enterprises.

The largest number of surveyed businesses operated in the service sector (48\%) and in the commercial sector (27\%). Companies active in the processing industry, the transport industry and the construction industry accounted for a total of $15 \%$ of the sample. $10 \%$ of the surveyed companies were active in other sectors.

Among the 100 surveyed businesses, $40 \%$ have been in the market for less than 3 years. $32 \%$ of companies have been active for 4 to 7 years. over the last 12 to 15 years (28\%) 20\% of the companies surveyed benefited from the assistance of external IT experts once, the remainder benefited from this eventuality more than once.

\section{RESULTS AND DISCUSSION}

Results of the empirical research have shown that IT is the area of activity most often outsourced (35\% of separated functions). $49 \%$ of the surveyed firms confirmed that cooperation with an external expert resulted in the creation of innovation. These included product innovation (30\% of indications), organisational innovation ( $30 \%$ of indications) and organisational innovations ( $30 \%$ of indications). $60 \%$ of investigated firms remain satisfied with the cooperation, and a further $50 \%$ of firms are interested in implementing IT innovations over the next decade.

The firms examined exchanged the benefits of working with an IT outsourcing partner:

- guarantee of one-stop operation of the systems ( $25 \%$ of indications),

- the ability to focus on key activities (30\% of indications),

- access to knowledge on the organisation of IT work ( $40 \%$ of indications),

- access to modern IT technologies (5\% of indications),

- consulting included in the price of the service (30\% of indications),

- financial benefits (m.in a constant level of service costs, a guarantee of the selection of optimal IT solutions tailored to the needs of business, a guarantee of cost reduction in IT service, reduction of costs associated with upgrading the qualifications of employees (30\% of indications).

Using the $\chi 2$ independence test showed a relationship between the benefits achieved in connection with the implementation of innovations as a result of outsourcing cooperation and activities that are to ensure proper cooperation with an external company $\left(\chi^{2}=\right.$ 76.76 at the significance level $p<0.05)$. The calculations proved that there is a relationship between benefits and actions. 
Just $90 \%$ of investigated SMEs declared to have taken actions to ensure proper cooperation with an external company (while the number of SMEs that did not take such actions was 10). Just $80 \%$ of the investigated SMEs declared the level of benefits achieved in connection with the implementation of innovations as a result of outsourcing cooperation for the ordering company measured by reducing costs above $20 \%$ and increasing sales above $20 \%$ (while the number of SMEs not achieving benefits was 20 ).

The results of the empirical research confirmed that there is a relationship between the benefits achieved in connection with the implementation of innovations as a result of outsourcing cooperation and activities that are to ensure proper cooperation with an external firm. It also seems interesting to compare the obtained results for this article with other studies. The results of the research on the outsourcing of IT services are consistent with the results of Accenture's analyses. These studies, like this empirical research, indicated that IT is the area of activity most frequently outsourced. Accenture reports that this is $30 \%$ of outsourced functions. According to the responses of the surveyed respondents in this study, this number is $35 \%$. The reason for the observed discrepancies in the research results may be the selection and size of the research sample - in the case of the research presented in this article, it was unfortunately not representative. The identified discrepancies justify further research in this area on a larger sample of companies.

\section{CONCLUSIONS}

IT outsourcing remains an important factor that largely influences the stimulation of innovation processes. This cooperation significantly influences the development of product innovations. Moreover, participation in the market network allows for the creation of organizational innovations.

The review of the scientific literature shows the positive impact of establishing outsourcing cooperation on the creation of innovation. This is the result of several issues:

- outsourcing cooperation in the field of IT facilitates the process of commercialization of innovations and their diffusion for the company with which the partnership was established,

- IT outsourcing has a huge impact on the development of IT knowledge,

- by establishing an outsourcing partnership in the IT area, it becomes possible to involve specialists from various scientific fields,

- outsourcing cooperation allows access to unique resources,

- the possibility of sharing the costs of R\&D works has become a huge benefit,

- cooperation with other organizations allows to expand the amount of available knowledge and improves the absorption capacity of the firm.

It should be emphasized how important it is to make entrepreneurs aware of the advantages of outsourcing partnership in the IT area in terms of creating innovation. A good practice in this respect would be to create a zone of redistribution of experience in implementing IT innovations.

In addition, it is also necessary to make managers aware that it is people who determine the essence and raison d'être of an organization through their potential for creativity, abilities, skills, knowledge and motivation. Other elements of building a competitive advantage are easier to copy than the company's personnel system, which is based 
on the uniqueness of people and organizational cultures. Properly shaped personnel policy may therefore decide about the success of introduced changes or innovations, and, consequently, about the high position of the company on the market. That is why an appropriate HR policy is so important for the employees of the parent company (who will have to work with the external team) and for the personnel of the external unit. One of the most important issues in implementing an outsourcing project is taking into account the views and opinions of both parties.

We realize that the conducted research was not representative. Due to the high cost of conducting the research. We included in the research sample only those entities that expressed their willingness to answer.

There is the need for further research. It would be interesting to determine statistical dependencies between the presence of a system of criteria and measures assessing the effectiveness of the implemented outsourcing process and the degree of satisfaction of this company with outsourcing cooperation, as well as the relationship between taking actions to ensure proper cooperation with an external company and the level of benefits achieved as a result of outsourcing cooperation for the company the ordering party.

\section{REFERENCES}

Aalders, R. (2001). The IT outsourcing guide. New Jersey: John Wiley \& Sons Ltd.

Aarikka-Stenroos, L., Sandberg, B., \& Lehtimäki, T. (2014). Networks for the commercialization of innovations: A review of how divergent network actors contribute. Industrial Marketing Management, 10 (3), 365-381.

Cho, H.J., \& Pucik, V. (2005). Relationship between Innovativeness, Quality, Growth. Profitability, and Market Value. Strategic Management Journal, 60 (26), 556.

Danneels, E., \& Kleinschmidt, E.J. (2016). Product Innovativeness from the Firm `s Perspective: Its Dimensions and their Impact on Project Selection and Performance. Institute for the Study of Business Markets, The Pennsylvania State University.

Dewick, P., \& Miozzo, M. (2004). Networks and innovation: sustainable technologies in Scottish social housing. $R \& D$ Management, 54 (3), 323-333.

Hakanson, H., \& Snehota, I. (2006). No Business is an island: The network concept of business strategy. Scandinavian Journal of Management, 10 (3), 256-270.

Hilami, M.F., Ramayah, T., Mustapha, Y., \& Pawanchik, S. (2010). Product and Process Innovativeness: Evidence from Malaysian SMEs. European Journal of Social Science, 60 (16), 557.

Hindle, T. (1998). Pocet Strategy. The Economist Newspaper Ltd in association with Profile Book.

Kern, T., Kern, T., Willcocks, L., \& Van Heck, E. (2002). The winner`s curse in IT outsourcing: strategies for avoiding relational trauma. California Management Review, 44 (2), 149-150.

Kim, Y., \& Lui, S. (2015). The impacts of external network and business group on innovation: Do the types of innovation matter? Journal of Business Research, 44 (9), 1964-1973.

Klimas, P. (2014). Sieci innowacji. Implikacja bliskości organizacyjnej. Katowice: Wydawnictwo Uniwersytetu Ekonomicznego w Katowicach.

Klincewicz, K. (2014). Tworzenie innowacji przez współpracę międzyorganizacyjną. In A.K. Koźmiński, \& D. Latusek-Jurczak (Eds.), Relacje międzyorganizacyjne w naukach o zarzq̨dzaniu (pp. 257258). Warszawa: Wolters Kluwer Business.

Kłos, M. (2009). Outsourcing w polskich przedsiębiorstwach. Warszawa: CeDeWu. 
Kodama, M. (2007). Innovation and knowledge creation through leadership-based strategic community: Case study on high-tech company in Japan. Technovation, 40 (3), 115-132.

Lacity, M.C., \& Hirschheim, R. (1993). Information Systems Outsourcing - Myths, Metaphors and Realities. New Jersey: John Wiley \& Sons Ltd.

Luecke, R., Katz, R. (2005). Zarzq̨dzanie kreatywnościq i innowacjq. Warszawa: MT Biznes.

Niedzielski, P. (2005). Innowacyjność. In K.B. Matusiak (Ed.), Innowacje i transfer technologii. Słownik pojęć (pp. 119-120). Warszawa: Polska Agencja Rozwoju Przedsiębiorczości.

Nowacki R. (2010). Innowacyjność w zarzq̨dzaniu a konkurencyjność przedsiębiorstwa. Warszawa: Difin.

Partanen, J., Chetty, S.K., \& Rajala, A. (2014). Innovation types and network relationships. Entrepreneurship Theory \& Practice, 30 (5), 1027-1055.

Pichlak, M. (2012). Uwarunkowania innowacyjności organizacji. Studium teoretyczne i wyniki badań. Warszawa: Difin.

Sankowska, A. (2009). Organizacja wirtualna: koncepcja i jej wpływ na innowacyjność. Warszawa: Wydawnictwa Akademickie i Profesjonalne.

Sobińska, A., \& Jakubowska, W. (2013). Zasoby a konkurencyjność i wyniki przedsiębiorstwa przgląd wybranych badań. In R. Bartkowiak, \& P. Wachowiak (Eds.), Wiedza i bogactwo narodów. Kapitał ludzki, globalizacja i regulacja w skali światowej (pp. 21-24). Warszawa: Oficyna Wydawnicza Szkoły Głównej Handlowej.

Sobińska, M. (2008). Zarzqdzanie outsourcingiem informatycznym. Wrocław: Wydawnictwo Aka-demii Ekonomicznej we Wrocławiu.

Szymaniak, A. (2008). Globalizacja usług - Outsourcing, Offshoring i Shares Services Centres. Warszawa: Wydawnictwa Akademickie i Profesjonalne.

Zakrzewska-Bielawska, A. (2016). Potencjał relacyjny a innowacyjność przedsiębiorstwa - w kierunku open innovation. Management Forum, 12 (1), 6-8. 


\section{Authors}

Contribution share of authors is equal and amounted to $50 \%$ for each of them.

\section{Maria Kocot}

Assistant professor at the University of Economics in Katowice (Poland) at the Department of Economic Informatics. PhD in economics (2009), Master of economics (2004). She is the author of scientific articles in the field of management and economics.

Correspondence to: dr Maria Kocot, University of Economics in Katowice, Department of Economic Informatics, ul. 1 Maja 50, 40-287 Katowice, Poland, e-mail: maria.kocot@ue.katowice.pl ORCID (1) http://orcid.org/0000-0001-5150-3765

\section{Damian Kocot}

Assistant professor at the University of Economics in Katowice (Poland) at the Department of Economic Informatics. PhD in management (2011). He is the author of scientific articles in the field of management and economics.

Correspondence to: dr Damian Kocot, University of Economics in Katowice, ul. 1 Maja 50, 40-287 Katowice, Poland, e-mail: damian.kocot@ue.katowice.pl

ORCID (1) http://orcid.org/0000-0001-9240-857X

\section{Copyright and License}

This article is published under the terms of the Creative Commons

Attribution - NoDerivs (CC BY-ND 4.0) License

http://creativecommons.org/licenses/by-nd/4.0/

Published by Cracow University of Economics - Krakow, Poland

The journal is co-financed in the years $2019-2020$ by the Ministry of Science and Higher Education of the Republic of Poland in the framework of ministerial programme "Support for Scientific Journals" (WCN) on the basis of contract no. 238/WCN/2019/1 concluded on 15 August 2019. 
